\title{
THE EFFECTS OF TWIN-ROW PLANTING PATTERN AND PLANT POPULATION ON SEED YIELD AND YIELD COMPONENTS OF SOYBEAN AT LATE DOUBLE-CROPPED PLANTING IN CUKUROVA REGION
}

\author{
Leyla GULLUOGLU ${ }^{1}$, Halil BAKAL ${ }^{2}$, Halis ARIOGLU ${ }^{2 *}$ \\ ${ }^{1}$ Cukurova University, Vocational School of Ceyhan, Adana, TURKEY \\ ${ }^{2}$ Cukurova University, Faculty of Agriculture, Department of Field Crops, Adana, TURKEY \\ *Corresponding author: halis@cu.edu.tr
}

Received: 05.01.2016

\begin{abstract}
This study was conducted at the experimental area of Department of Field Crops, Faculty of Agriculture, Cukurova University in 2013 and 2014. The objective of this study was to determine the influence of planting pattern and plant population on seed yield and yield components of soybean at late double-cropped (after $15^{\text {th }}$ of July) planting in Cukurova region, Turkey. The experimental design was a Randomized Complete Block Design with three replications. The Atakisi (maturity group III) variety was used as a plant material in this research. The planting pattern was used as twin-row and conventional single-row. The row spacing was $70 \mathrm{x}$ $25 \times 70 \mathrm{~cm}, 75 \times 25 \times 75 \mathrm{~cm}$ and $80 \times 25 \times 80 \mathrm{~cm}$ for twin-row and $70 \mathrm{~cm}$ for single-row pattern. Intra-row spacing of 3, 4, 5 and $6 \mathrm{~cm}$ was arranged for different plants population. In this research, the plant populations varied between 31.6 and 69.9 plants $\mathrm{m}^{-2}$. According to a two-year average, the highest seed yield $\left(4906 \mathrm{~kg} \mathrm{ha}^{-1}\right)$ was obtained from $80 \times 25 \times 80 \times 3 \mathrm{~cm}\left(63.2\right.$ plants $\left.\mathrm{m}^{-1}\right)$ twin-row planting pattern while the yield was $3940 \mathrm{~kg}$ $\mathrm{ha}^{-1}$ in single-row planting pattern as $70 \times 4 \mathrm{~cm}\left(35.7\right.$ plants $\left.\mathrm{m}^{-1}\right)$. The yield increase was $24.5 \%$ more than conventional single-row planting pattern (standard).
\end{abstract}

Key words: Double-cropped, Plant population, Planting pattern, Soybean, Twin-row

\section{INTRODUCTION}

Soybean [Glycine $\max ($ L.) Merr.] seed contains $21 \%$ oil, $40 \%$ protein, $34 \%$ carbohydrates and $5 \%$ ash on a dry matter basis. For this reason, it is an important source of edible vegetable oil and protein for both human nutrition and animal feeding. It uses for vegetable oil production and livestock feed in the world. Soybean is a legume crop and it improves soil fertility by fixing atmospheric nitrogen (Gulluoglu et al., 2010 and Arioglu, 2014).

Soybean has been grown mainly as a double-cropped after a small grain harvest in the Cukurova region in Turkey. The share of the double-cropped was $70 \%$ in the total Turkey soybean planting area of 34.000 ha. Cukurova is the major soybean production area in Turkey with $90 \%$ production share (Anonymous, 2014a).

The main competition factors can be identified as light, water and nutrients for plants. The competition between the plants can be regulated by the optimum plant number per unit area. Planting density is an important factor for soybean growth and seed yield. When planting density is high, the branching of each plant is depressed and the number of the lateral stem decrease. In addition, under high planting density the competition for photosynthesis and nutrient absorption among plants become severe and the stem grows tall and thin. Generally, soybean grown in high plant density produces a higher yield than of those grown in low density (Egli, 1988; Aslam et al., 1993; Hosseini et al., 2001; Calışkan et al., 2007; Liu et al., 2010; Cox and Cherney, 2011; Worku and Astatkie, 2011; Rahman and Hossain, 2011; Zhou et al., 2011; Bruns, 2011; Shamsi and Kobraee, 2011 and Akond et al., 2013).

The seed planting starts first week of June and continues to mid of July in double-cropped soybean farming in Turkey. Soybean is classified as short day plant because short days initiate the flowering process. Soybeans will flower very soon after emerge if the day length is short. For this reason, when the planting delayed after June 21, the vegetative growth stage of plants shortened and plants start to flowering due to short day conditions. Other side, in this conditions the plants can not grow tall and the number of the lateral stem decrease. As a result, pod number per plant was decreased and the seed yield was lowered. Two agronomic traits of average seed size and number of seeds per unit area directly affect of the yield (Ohyama et al., 2013). In soybean crop, these parameters can be described in terms of average number 
of seeds per pod, average number of pods per plant, and number of plants per unit area Soybean seed yield is calculated by multiplying the plant number per unit area $\mathrm{x}$ pod number per plant $\mathrm{x}$ seed number per pod $\mathrm{x}$ one average seed weight (Aslam et al., 1993). It is necessary to increase the plant number per unit area to compensate to reduction of pod number per plant at late planting double crop soybean farming. Increasing the plant number per unit area, it is necessary to reduce the plant space on the rows. The plants grow thin and weak for competition and the pod number per plant is decreases. It is possible to increase the number of plant per unit area by the Twinrow planting pattern.

High plant populations provide a way to optimize grain yield in short-season production systems. Twin-row planting pattern is very important at late planting doublecropped soybean production. Several experiments conducted on twin-row planting pattern and plant population under different soil and climatic conditions indicated that yield is higher in twin-row planting than single-row planting (Ikeda, 1992; Bell, 2005; Koger, 2007; Mascagni et al., 2008; Stalcup, 2009 and Bruns, 2011).

Usually single-row planting pattern and 135.142 plant $\mathrm{ha}^{-1}(70 \times 4 \mathrm{~cm})$ plant density were applying in doublecropped soybean production in Cukurova region, Turkey. Twin-row planting pattern was not used so far in soybean production in Cukurova region.

The objective of this study was to determine the influence of twin-row planting pattern and plant population on seed yield and yield components of soybean at late double-cropped planting in Cukurova region, Turkey.

\section{MATERIALS AND METHODS}

\section{Materials}

Field experiments were conducted in 2013 and 2014 as a second crop after wheat harvesting, between July and October at the Cukurova University research farm in Adana, Turkey (Southern Turkey, 36 59 N, 35²18 E; 23 elevation). The Atakisi variety was used as a plant material in this research. Atakisi is medium early (maturity group III) and high-yielding indeterminate soybean variety.

The texture of the soil was clay loam. The salt content of the soil was low. The soil tests in both years indicated a $\mathrm{pH}$ of 7.7 with high concentrations of $\mathrm{K}_{2} \mathrm{O}$ and low concentrations of $\mathrm{P}_{2} \mathrm{O}_{5}$. In addition, the organic matter and nitrogen content of the soil was very low. The lime content was $24.13 \%$ in the upper layers with increased levels in lower layers.

In the Adana province of Turkey, winters are mild and rainy, whereas summers are dry and warm, which is a typical of a Mediterranean climate. The average monthly air temperature during the research period (JulyOctober) was 19.5 to $28.6{ }^{\circ} \mathrm{C}$ in 2013 , whereas it was in 21.0 to $29.1{ }^{\circ} \mathrm{C}$ range in 2014 . The total rainfall was 31.5 $\mathrm{mm}$ and $148.8 \mathrm{~mm}$ during the growing periods in 2013 and 2014 , respectively. The average relative humidity was ranged from $47.9 \%$ to $69.0 \%$ in 2013 and $62.9 \%$ to $72.6 \%$ in 2014 (Table 1).

Table 1. The average monthly temperature, monthly precipitation and relative humidity at Adana-Turkey, during the 2013 and 2014 growing seasons (Anonymous, 2014b)

\begin{tabular}{lcccccc}
\hline \multirow{2}{*}{ Months } & \multicolumn{2}{c}{ Avg. temperature $\left({ }^{\mathbf{0}} \mathbf{C}\right)$} & \multicolumn{2}{c}{ Precipitation $(\mathbf{m m})$} & \multicolumn{2}{c}{ Relative humidity $(\%)$} \\
\cline { 2 - 7 } & $\mathbf{2 0 1 3}$ & $\mathbf{2 0 1 4}$ & $\mathbf{2 0 1 3}$ & $\mathbf{2 0 1 4}$ & $\mathbf{2 0 1 3}$ & $\mathbf{2 0 1 4}$ \\
\hline July & 28.2 & 28.2 & 0.0 & 0.3 & 65.2 & 72.6 \\
August & 28.6 & 29.1 & 0.0 & 0.3 & 69.0 & 70.3 \\
September & 25.3 & 25.9 & 15.0 & 80.4 & 63.1 & 64.1 \\
October & 19.5 & 21.0 & 16.5 & 67.8 & 47.9 & 62.9 \\
\hline
\end{tabular}

\section{Method}

The experimental design used in this study was a Randomized Complete Block replicated three times. The experimental site was cultivated deeply by the diskedharrowed after wheat harvesting in both years. Before planting, $200 \mathrm{~kg} \mathrm{ha}^{-1}$ of DAP $\left(36 \mathrm{~kg} \mathrm{ha}^{-1} \mathrm{~N}, 92 \mathrm{~kg} \mathrm{ha}^{-1} \mathrm{P}\right)$ fertilizers were applied. Mineral fertilizer rates were determined based the nutritional requirements of soybean and soil nutrient availability. Weed control was accomplished at both years with a pre-plant application of Treflan (trifluralin) at amount of $1.5 \mathrm{~L} \mathrm{ha}^{-1}$. The plot size was varied from $14.0 \mathrm{~m}^{2}$ to $21.0 \mathrm{~m}^{2}$ according to planting pattern and row distance. Twin-row and single-row planting patterns were sown in Figure 1. Plots were planted by hand in the $17^{\text {th }}$ of July in both years. Before planting, all seeds were inoculated with Bradyrhizobium japonicum bacteria.

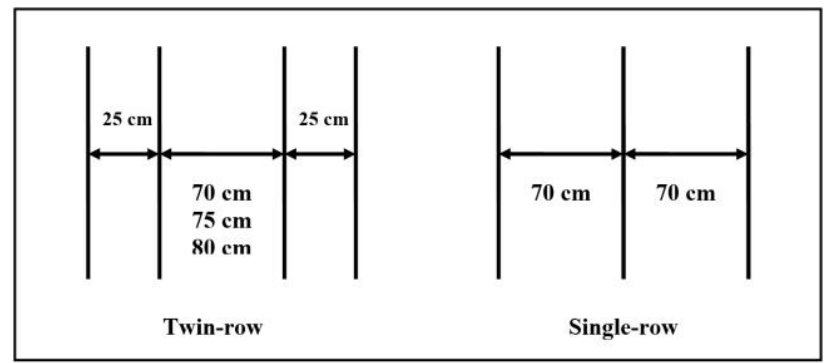

Figure 1. Twin-row and single-row planting patterns

During the growing period, recommended pesticides were applied to control insects and diseases. Plots at both 
years were furrow irrigated beginning at R1 (beginning flowering) and continuing to R6 (full seed). Approximately $30 \mathrm{~mm}$ of water was applied at about 15 day intervals. During the growing period, other standard cultural practices were applied at proper time intervals.
The soybean seeds were planted at a high density at planting and then plant distance (plant density) was regulated by pulling out plants (thinning) at the $\mathrm{V} 2$ growth stage (two trifoliolate leaf nodes). The planned of planting patterns and plant populations are given in Table 2.

Table 2. The planned planting patterns and plant populations in experiment

\begin{tabular}{ccccc}
\hline Planting patterns & $\begin{array}{c}\text { Row spacing } \\
(\mathbf{c m})\end{array}$ & $\begin{array}{c}\text { Plant spacing } \\
(\mathbf{c m})\end{array}$ & $\begin{array}{c}\text { Plant numbers } \\
\left(\text { plant } \mathbf{~ m}^{-\mathbf{1}}\right)\end{array}$ & $\begin{array}{c}\text { Seeding rate* } \\
\left(\mathbf{k g ~ h a} \mathbf{~}^{-\mathbf{1}}\right)\end{array}$ \\
\hline Twin-row & & & & \\
Twin-row & $70 \times 25$ & 3 & 69.9 & 108.7 \\
Twin-row & $70 \times 25$ & 4 & 52.6 & 81.9 \\
Twin-row & $70 \times 25$ & 5 & 42.1 & 65.4 \\
Twin-row & $70 \times 25$ & 6 & 34.9 & 54.3 \\
Twin-row & $75 \times 25$ & 3 & 66.4 & 103.3 \\
Twin-row & $75 \times 25$ & 4 & 50.0 & 77.8 \\
Twin-row & $75 \times 25$ & 5 & 40.0 & 62.2 \\
Twin-row & $75 \times 25$ & 6 & 33.2 & 51.7 \\
Twin-row & $80 \times 25$ & 3 & 63.2 & 98.7 \\
Twin-row & $80 \times 25$ & 4 & 47.6 & 74.1 \\
Twin-row & $80 \times 25$ & 5 & 38.1 & 59.2 \\
Single-row** & $80 \times 25$ & 6 & 31.6 & 49.2 \\
\hline *100 & 70 & 4 & 35.7 & 55.6 \\
\hline seed weight was 14.0 g and seed germination was 90\%.** Single-row $(70 \times 4 \mathrm{~cm})$ is a conventional planting pattern in Cukurova
\end{tabular}

\section{Measurement of characteristics}

Data was measured from the 10 pants which were randomly selected from the central rows of each plot and then cut from the ground just before harvest. Average plant height $(\mathrm{cm})$, the lowest pod height $(\mathrm{cm})$, branch number (no.plant ${ }^{-1}$ ) and pod number (no. plant ${ }^{-1}$ ) were calculated as the quotient of their respective values and the number of sampled plants $(n=10)$. Yield data per plot was measured in a similar way from all remaining plants excluding the very end on each side of the two central rows. 100-seed weight (g), oil content (\%) and crude oil yield $\left(\mathrm{kg} \mathrm{ha}^{-1}\right)$ data were obtained after harvest (Zaimoglu et al., 2004).

Table 3. The effect of planting pattern and plant density on plant height $(\mathrm{cm})$ and the lowest pod height $(\mathrm{cm})$ at the late planting double cropped soybean production

\begin{tabular}{|c|c|c|c|c|c|c|c|}
\hline \multirow{2}{*}{$\begin{array}{l}\text { Row spacing } \\
\text { (cm) }\end{array}$} & \multirow{2}{*}{$\begin{array}{l}\text { Plant numbers } \\
\quad\left(\text { plant } \mathbf{~ m}^{-1}\right)\end{array}$} & \multicolumn{3}{|c|}{ Plant height (cm) } & \multicolumn{3}{|c|}{ Lowest pod height $(\mathrm{cm})$} \\
\hline & & 2013 & 2014 & Mean & 2013 & 2014 & Mean \\
\hline $70 \times 25-3^{*}$ & 69.9 & 86.6 & 103.4 & 95.0 & 19.6 & 22.5 & 21.1 \\
\hline $70 \times 25-4 *$ & 52.6 & 88.1 & 103.2 & 95.7 & 18.0 & 21.2 & 19.6 \\
\hline $70 \times 25-5^{*}$ & 42.1 & 83.7 & 98.8 & 91.3 & 14.6 & 20.3 & 17.5 \\
\hline $70 \times 25-6^{*}$ & 34.9 & 80.8 & 96.9 & 88.8 & 14.2 & 19.4 & 16.8 \\
\hline $75 \times 25-3^{*}$ & 66.4 & 90.2 & 98.4 & 94.3 & 17.9 & 22.0 & 19.9 \\
\hline $75 \times 25-4^{*}$ & 50.0 & 82.1 & 98.8 & 90.5 & 17.2 & 21.6 & 19.4 \\
\hline $75 \times 25-5^{*}$ & 40.0 & 86.9 & 98.9 & 92.9 & 16.5 & 21.8 & 19.2 \\
\hline $75 \times 25-6^{*}$ & 33.2 & 83.8 & 96.9 & 90.4 & 16.9 & 19.6 & 18.3 \\
\hline $80 \times 25-3 *$ & 63.2 & 83.9 & 98.0 & 90.9 & 14.9 & 22.6 & 18.8 \\
\hline $80 \times 25-4^{*}$ & 47.6 & 81.1 & 97.7 & 89.4 & 16.2 & 21.7 & 18.9 \\
\hline $80 \times 25-5^{*}$ & 38.1 & 83.5 & 96.8 & 90.1 & 17.4 & 21.2 & 19.3 \\
\hline $80 \times 25-6^{*}$ & 31.6 & 84.5 & 95.3 & 89.9 & 16.5 & 19.6 & 18.0 \\
\hline $70 \times 4 * *$ & 35.7 & 82.1 & 95.5 & 88.8 & 15.0 & 18.4 & 16.7 \\
\hline LSD (5\%) & - & N.S & N.S & N.S & N.S & N.S & N.S \\
\hline
\end{tabular}

The data were statistically analyzed by using MSTATC package program with Randomized Complete Block Design. The Least Significant Differences (LSD) test was used to compare the treatments at 0.05 level.

\section{RESULTS AND DISCUSSION}

\section{The Plant Height and Lowest Pod Height}

The data belonging to plant height and the lowest pod height at different planting pattern and plant densities at late planting double cropped soybean production are presented in Table 3.

*Twin-row, ${ }^{*}$ Single-row 
The plant height values varied between $80.8-90.2 \mathrm{~cm}$ in 2013, and between 95.3-103.4 cm in 2014 (Table 3). The differences between the plant densities were not statistically significant in 2013 and 2014. The plant height in 2014 was higher when compared to 2013, because of the rainy weather after the emergence of the plants to the soil surface in 2014. This rainfall stimulated vegetative growth of the soybean plants and the plant height increased. The plant height varied between $88.8 \mathrm{~cm}$ and $103.4 \mathrm{~cm}$ in the two-year study (Table 3 ). As the plant density was increased in per unit area, plant height increased substantially. The competition between the plants increased to use more solar energy at high plant density. Similar results were reported by other researchers (Cox and Cherney, 2011; Rahman and Hossain, 2011 and Akond et al., 2013).

The lowest pod height is an important plant parameter to reduce harvest loss in soybean farming. Pods too close to the soil surface increase harvest losses since some combine harvester heads are unable to pick up the bottom pods.

The lowest pod height values varied between 14.2 and $19.6 \mathrm{~cm}$ in 2013; between 18.4 and $22.6 \mathrm{~cm}$ in 2014 (Table 3). The differences between the plant densities were not statically important in 2013 and 2014. Plants were significantly podded higher up the stem in 2014 than in 2013. The rainfall just after emergence stimulated vegetative growth of the soybean plants and it delayed flowering. For this reason, the bottom pod height was increased. According to two-year average, bottom pod height was varied between $16.7 \mathrm{~cm}$ and $21.1 \mathrm{~cm}$. While the bottom pod height was $16.7 \mathrm{~cm}$ at standard planting pattern (plant density 35.7 plant $\mathrm{m}^{-1}$ ), it increased up to $21.1 \mathrm{~cm}$ at twin-row planting pattern (plant density 69.9 plant $\mathrm{m}^{-1}$ ). As the plant density increased in per unit area, plant height and bottom pod height increased substantially. As a result; the differences between the plant densities were not statically important. Similar results were supported by the findings by Aslam et al. (1993).

\section{Branches Number and Pods Number}

The data belonging to branches number and pods number per plant at different planting pattern and plant densities at late planting double cropped soybean production are presented in Table 4

It can be seen in Table 4, the differences between the plant densities were not significant for number of branches in 2013, but it was significant in 2014. The branch number varied from 2.10 to 2.98 in a two-year average. Soybean produced more branches per plant at low plant densities ( 31.6 plant $\mathrm{m}^{-1}$ ) compared with the high plant densities (69.9 plant $\left.\mathrm{m}^{-1}\right)$. At low plant density, existing plants developed more branches because of reduced in competition. When planting density is high, the branching of each plant is depressed and the number of the lateral stem decrease. These results are in agreement with the findings of Hosseini et al. (2001); Dapaah et al. (2005); Cox and Cherney (2011); Worku and Astatkie (2011); Rahman and Hossain (2011) and Shamsi and Kobraee (2011).

Table 4. The effect of planting pattern and plant density on branches number per plant (no. plant ${ }^{-1}$ ) and pods number per plant (no. plant $^{-1}$ ) at the late planting double cropped soybean production

\begin{tabular}{|c|c|c|c|c|c|c|c|}
\hline \multirow{2}{*}{$\begin{array}{c}\text { Row spacing } \\
\text { (cm) }\end{array}$} & \multirow{2}{*}{$\begin{array}{c}\text { Plant } \\
\text { numbers } \\
\left(\text { plant } \mathbf{m}^{-1}\right)\end{array}$} & \multicolumn{3}{|c|}{$\begin{array}{c}\text { Branches per plant } \\
\left(\text { no. plant }{ }^{-1}\right)\end{array}$} & \multicolumn{3}{|c|}{$\begin{array}{l}\text { Pods per plant } \\
\left(\text { no. plant }^{-1}\right)\end{array}$} \\
\hline & & 2013 & 2014 & Mean & 2013 & 2014 & Mean \\
\hline $70 \times 25-3^{*}$ & 69.9 & 2.33 & $2.03 \mathrm{bc}$ & 2.18 & $45.4 \mathrm{e}$ & $46.0 \mathrm{f}$ & $45.7 \mathrm{~h}$ \\
\hline $70 \times 25-4^{*}$ & 52.6 & 2.63 & $2.43 \mathrm{abc}$ & 2.53 & $49.4 \mathrm{de}$ & 50.0 ef & $49.7 \mathrm{fgh}$ \\
\hline $70 \times 25-5^{*}$ & 42.1 & 2.77 & $2.30 \mathrm{abc}$ & 2.53 & 55.7 bcde & 56.2 cde & $56.0 \mathrm{def}$ \\
\hline $70 \times 25-6^{*}$ & 34.9 & 2.87 & $2.60 \mathrm{ab}$ & 2.73 & $58.7 \mathrm{abcd}$ & $61.0 \mathrm{bc}$ & $59.9 \mathrm{bcd}$ \\
\hline $75 \times 25-3 *$ & 66.4 & 2.63 & $1.67 \mathrm{c}$ & 2.15 & $48.1 \mathrm{de}$ & 49.9 ef & $49.0 \mathrm{gh}$ \\
\hline $75 \times 25-4 *$ & 50.0 & 2.53 & $1.67 \mathrm{c}$ & 2.10 & $52.3 \mathrm{cde}$ & $53.6 \mathrm{de}$ & $53.0 \mathrm{efg}$ \\
\hline $75 \times 25-5^{*}$ & 40.0 & 2.93 & $2.40 \mathrm{abc}$ & 2.67 & $60.7 \mathrm{abc}$ & $60.0 \mathrm{bcd}$ & $60.4 \mathrm{bcd}$ \\
\hline $75 \times 25-6^{*}$ & 33.2 & 2.73 & $2.67 \mathrm{ab}$ & 2.70 & $66.3 \mathrm{ab}$ & $64.7 \mathrm{ab}$ & $65.5 \mathrm{ab}$ \\
\hline $80 \times 25-3 *$ & 63.2 & 2.63 & $1.63 \mathrm{c}$ & 2.13 & 55.7 bcde & 55.2 cde & $55.5 \mathrm{def}$ \\
\hline $80 \times 25-4 *$ & 47.6 & 2.83 & $2.67 \mathrm{ab}$ & 2.75 & $58.0 \mathrm{abcd}$ & $59.5 \mathrm{bcd}$ & $58.8 \mathrm{cde}$ \\
\hline $80 \times 25-5^{*}$ & 38.1 & 2.70 & $2.97 \mathrm{a}$ & 2.83 & $62.2 \mathrm{abc}$ & $64.9 \mathrm{ab}$ & $63.6 \mathrm{abc}$ \\
\hline $80 \times 25-6^{*}$ & 31.6 & 2.93 & $3.03 \mathrm{a}$ & 2.98 & $67.4 \mathrm{a}$ & $69.0 \mathrm{a}$ & $68.2 \mathrm{a}$ \\
\hline $70 \times 4 * *$ & 35.7 & 3.13 & $2.67 \mathrm{ab}$ & 2.90 & $60.8 \mathrm{abc}$ & $61.3 \mathrm{bc}$ & $61.1 \mathrm{bcd}$ \\
\hline LSD (5\%) & - & N.S & 0.820 & N.S & 10.87 & 6.818 & 5.238 \\
\hline
\end{tabular}

*Twin-row, **Single-row

There was a statistically significant difference in pod number per plant between plant densities in different planting pattern in both years. The pod number per plant values varied between 45.4 and 67.4 in 2013, and between 46.0-69.0 in 2014 (Table 4). There was a significant effect of plant density on pod number per plant.
The differences between the plant densities were statistically significant in a two-year average. The number of pods per plant varied from 45.7 to 68.2 in 2013 and 2014 years average. By increasing intra-row spacing at the same row spacing in twin-row planting pattern, the number of pods per plant was significantly increased in 
both years (Table 4). The pod number increase in the low plant density was a result of extra branching. At low density, existing plants developed more branches and pods because of reduced in competition. The number of pods and branches per plant tended to decrease with increased population density. These findings are supported by Aslam et al. (1993); Hosseini et al. (2001); Dapaah et al. (2005); Liu et al. (2010); Cox and Cherney (2011);
Shamsi and Kobraee (2011); Bruns (2011) and Akond et al. (2013).

\section{0-Seed Weight and Seed Yield}

The data belonging to 100 -seed weight and seed yield at different planting pattern and plant densities at late planting double cropped soybean production are presented in Table 5.

Table 5. The effect of planting pattern and plant density on 100-seed weight $(\mathrm{g})$ and seed yield $\left(\mathrm{kg} \mathrm{ha}^{-1}\right)$ at the late planting double cropped soybean production

\begin{tabular}{|c|c|c|c|c|c|c|c|}
\hline \multirow{2}{*}{$\begin{array}{c}\text { Row spacing } \\
(\mathbf{c m})\end{array}$} & \multirow{2}{*}{$\begin{array}{l}\text { Plant numbers } \\
\left.\text { (plant } \mathbf{~ m}^{-1}\right)\end{array}$} & \multicolumn{3}{|c|}{ 100-Seed weight (g) } & \multicolumn{3}{|c|}{ Seed yield $\left(\mathrm{kg} \mathrm{ha}^{-1}\right)$} \\
\hline & & 2013 & 2014 & Mean & 2013 & 2014 & Mean \\
\hline $70 \times 25-3^{*}$ & 69.9 & 13.61 & 14.16 & 13.89 & $4530 \mathrm{ab}$ & $4558 \mathrm{bcd}$ & $4544 \mathrm{ab}$ \\
\hline $70 \times 25-4 *$ & 52.6 & 13.67 & 14.35 & 14.01 & $4390 \mathrm{abcd}$ & 4330 bcde & $4360 \mathrm{bcd}$ \\
\hline $70 \times 25-5^{*}$ & 42.1 & 13.64 & 14.45 & 14.05 & 4007 bcde & 4193 de & 4100 def \\
\hline $70 \times 25-6^{*}$ & 34.9 & 13.62 & 14.76 & 14.19 & $3625 \mathrm{e}$ & $4042 \mathrm{e}$ & $3833 \mathrm{f}$ \\
\hline $75 \times 25-3 *$ & 66.4 & 13.65 & 14.35 & 14.00 & $4623 \mathrm{ab}$ & $4654 \mathrm{bc}$ & $4639 \mathrm{ab}$ \\
\hline $75 \times 25-4 *$ & 50.0 & 13.59 & 14.60 & 14.10 & 4347 abcd & $4635 \mathrm{bc}$ & $4491 \mathrm{bc}$ \\
\hline $75 \times 25-5^{*}$ & 40.0 & 13.58 & 14.71 & 14.14 & 4137 abcde & 4397 bcde & 4267 bcde \\
\hline $75 \times 25-6^{*}$ & 33.2 & 13.55 & 14.84 & 14.20 & 3933 bcde & 4330 bcde & 4132 cdef \\
\hline $80 \times 25-3 *$ & 63.2 & 13.69 & 14.70 & 14.15 & $4755 \mathrm{a}$ & $5057 \mathrm{a}$ & $4906 \mathrm{a}$ \\
\hline $80 \times 25-4 *$ & 47.6 & 13.68 & 14.72 & 14.20 & $4434 \mathrm{abc}$ & $4710 \mathrm{ab}$ & $4572 \mathrm{ab}$ \\
\hline $80 \times 25-5^{*}$ & 38.1 & 13.65 & 14.76 & 14.20 & 4045 bcde & 4617 bc & $4331 \mathrm{bcd}$ \\
\hline $80 \times 25-6^{*}$ & 31.6 & 13.62 & 14.77 & 14.20 & $3727 \mathrm{de}$ & 4297 cde & $4012 \mathrm{def}$ \\
\hline $70 \times 4 * *$ & 35.7 & 13.66 & 14.48 & 14.07 & 3814 cde & $4067 \mathrm{e}$ & 3940 ef \\
\hline $\operatorname{LSD}(5 \%)$ & - & N.S & N.S & N.S & 696.00 & $\mathbf{3 8 0 . 3 7}$ & 323.81 \\
\hline
\end{tabular}

*Twin-row, **Single-row

The 100 seed weight values varied between 13.55 $13.69 \mathrm{~g}$ in 2013, between 14.16-14.84 $\mathrm{g}$ in 2014 and between $13.89 \mathrm{~g}-14.20 \mathrm{~g}$ in two years average (Table 5). The 100 seeds weight in 2014 was heavier when compared to 2013. There was no statistically significant difference between the plant population densities in both years. These figures show that plant population densities were not affected on 100 seed weight at different planting pattern in soybean. Similar results were reported by other researchers (Dapaah et al., 2005; Liu et al., 2010; Rahman and Hossain, 2011; Worku and Astatkie, 2011 and Akond et al., 2013).

There was statistically significant difference in seed yields between plant population densities in both years and two years average. The seed yield values varied between $3625-4755 \mathrm{~kg} \mathrm{ha}^{-1}$ in $2013,4042-5057 \mathrm{~kg} \mathrm{ha}^{-1}$ in 2014, and 3833-4906 kg ha-1 in two years average (Table 5 ). The seed yield was significantly affected by the plant population density. Over the two years average, the highest seed yield (4906 $\mathrm{kg} \mathrm{ha}^{-1}$ ) was obtained from 63.2 plants $\mathrm{m}^{-1}$ plant density in twin-row planting pattern. Generally, the seed yield was higher in twin-row planting pattern than conventional (single-row) planting pattern. The seed yield per hectare continuously increased as intrarow spacing decreased from $6 \mathrm{~cm}$ to $3 \mathrm{~cm}$ in same row spacing in twin-row planting pattern. Soybean seed yield is calculated by multiplying the plant number per unit area $\mathrm{x}$ pod number per plant $\mathrm{x}$ seed number per pod $\mathrm{x}$ one average seed weight. Pod and seed number per plant are the very important seed yield components, and these parameters are very respond to changes in plant density. The pod number per plant was decreased, while the plant density increased (Table 4) in the same row spacing at twin-rows planting pattern. But, the seed yield per hectare was increased. Because, while the pod number per plant was decreasing in high plant density, the total pod number of per unit area was increased. For this reason, the seed yield per hectare was increased at high plant density in twin-rows planting pattern. Planting density is an important factor for soybean growth and seed yield. When planting density is high, the branching of each plant is depressed and the lateral stem and pod number of per plant decrease.

Soybean is classified as a short day plant. Soybean planting delayed after 21 of June, the vegetative growth stage of plants shortened and plants start to flowering due to short day conditions. Other side, in this conditions the plants can not grow tall and the number of the lateral stem decrease. As a result, pod number per plant was decreased and the seed yield was lowered. It is necessary to increase the plant number per unit area to compensate to reduction of pod number per plant at late planting double crop soybean farming. Increasing the plant number per unit area, it is necessary to reduce the plant space on the rows. The plants grow thin and weak for competition and the pod number per plant decreases when the row space reduced in single-row planting pattern (Aslam et al., 1993). It is not possible to increase plant number per unit 
area reducing row space in conventional single-row planting pattern, but it is possible by the twin-row planting pattern.

In this research, the seed planting was done 17 of July as late double cropping. Plants started to flowering after emerging to above ground surface due to short day conditions. For this reason, plants shortened and pod number per plant was decreased. The decrease of pod number per unit area was compensated by the increasing plant number per unit area planting twin-row pattern. As a result, pod number per unit area was increased and seed yield increased (Table 5). Soybean seed yield depends mostly on pod and seed number per area. Similar results were reported by other researchers (Egli, 1988; Aslam et al., 1993; Hosseini et al., 2001; Dapaah et al., 2005; Caliskan et al., 2007; Liu et al., 2010; Bruns, 2011; Rahman and Hossain, 2011; Shamsi and Kobraee, 2011; Zhou et al., 2011; Cox and Cherney, 2011; Worku and Astatkie, 2011; Akond et al., 2013 and El-Zeadani et al., 2014).

\section{Oil Content and Oil Yield}

The data belonging to oil content and oil yield at different planting pattern and plant densities at late planting double cropped soybean production are presented in Table 6.

Table 6. The effect of planting pattern and plant density on oil content and oil yield at the late planting double cropped soybean production

\begin{tabular}{|c|c|c|c|c|c|c|c|}
\hline \multirow{2}{*}{$\begin{array}{l}\text { Row spacing } \\
\text { (cm) }\end{array}$} & \multirow{2}{*}{$\begin{array}{c}\text { Plant } \\
\text { numbers } \\
\left(\text { plant } \mathbf{m}^{-1}\right)\end{array}$} & \multicolumn{3}{|c|}{ Oil content (\%) } & \multicolumn{3}{|c|}{ Oil yield (kg ha ${ }^{-1}$ ) } \\
\hline & & 2013 & 2014 & Mean & 2013 & 2014 & Mean \\
\hline $70 \times 25-3^{*}$ & 69.9 & 19.66 & 16.23 & 17.94 & $889.3 \mathrm{a}$ & 739.6 bcde & 814.5 abc \\
\hline $70 \times 25-4 *$ & 52.6 & 19.35 & 16.43 & 17.89 & $848.6 \mathrm{ab}$ & $711.5 \mathrm{de}$ & 780.1 bcde \\
\hline $70 \times 25-5^{*}$ & 42.1 & 18.84 & 17.15 & 17.99 & $753.6 \mathrm{bc}$ & $719.1 \mathrm{cde}$ & $735.3 \mathrm{def}$ \\
\hline $70 \times 25-6^{*}$ & 34.9 & 19.13 & 17.47 & 18.30 & $693.5 \mathrm{c}$ & $706.2 \mathrm{de}$ & $699.9 \mathrm{f}$ \\
\hline $75 \times 25-3 *$ & 66.4 & 19.48 & 16.75 & 18.11 & $900.6 \mathrm{a}$ & $779.3 \mathrm{abc}$ & $840.0 \mathrm{ab}$ \\
\hline $75 \times 25-4 *$ & 50.0 & 18.05 & 16.81 & 17.43 & $785.3 \mathrm{abc}$ & $779.1 \mathrm{abc}$ & 782.2 bcde \\
\hline $75 \times 25-5^{*}$ & 40.0 & 18.10 & 16.91 & 17.51 & $749.0 \mathrm{bc}$ & 743.7 bcd & $746.3 \mathrm{def}$ \\
\hline $75 \times 25-6^{*}$ & 33.2 & 18.09 & 16.97 & 17.53 & $709.5 \mathrm{c}$ & 733.8 bcde & 721.7 ef \\
\hline $80 \times 25-3^{*}$ & 63.2 & 18.96 & 16.65 & 17.81 & $901.8 \mathrm{a}$ & $841.9 \mathrm{a}$ & $871.9 \mathrm{a}$ \\
\hline $80 \times 25-4 *$ & 47.6 & 18.14 & 16.68 & 17.41 & $803.6 \mathrm{abc}$ & $784.5 \mathrm{ab}$ & $794.1 \mathrm{bcd}$ \\
\hline $80 \times 25-5^{*}$ & 38.1 & 18.81 & 16.28 & 17.55 & 758.6 bc & $751.6 \mathrm{bcd}$ & 755.1 cdef \\
\hline $80 \times 25-6^{*}$ & 31.6 & 18.82 & 16.39 & 17.61 & $701.7 \mathrm{c}$ & $703.6 \mathrm{de}$ & $702.7 \mathrm{f}$ \\
\hline $70 \times 4 * *$ & 35.7 & 18.76 & 16.66 & 17.71 & $717.8 \mathrm{c}$ & $677.3 \mathrm{e}$ & $697.6 \mathrm{f}$ \\
\hline LSD (5\%) & - & N.S & N.S & N.S & 118.04 & 63.19 & 54.66 \\
\hline
\end{tabular}

*Twin-row, **Single-row

There was no statistically significant difference in oil content between plant densities in either year. The oil content values varied between $17.41 \%-18.30 \%$ in a twoyear average (Table 6). The oil content values in 2013 was higher than 2014. But, oil content was not significantly affected by the plant population densities in different planting pattern in both years. The oil content in 2013 was higher than 2014. The oil content of soybean seed was affected by air temperature at the seed filling period (Bellaloui et al., 2015). The average air temperature at the seed filling period was higher in 2014 than 2013. The high air temperature had decreased oil content of soybean seed.

The oil yield values varied between $693.5-901.8 \mathrm{~kg} \mathrm{ha}^{-}$ 1 in 2013 and $677.3-841.9 \mathrm{~kg} \mathrm{ha}^{-1}$ in 2014. There was a statistically significant difference in oil yield per hectare between plant densities in different planting pattern in both years. For two years average, the oil yield per hectare varied from 697.6 to $871.9 \mathrm{~kg} \mathrm{ha}^{-1}$ (Table 6). The differences between the plant densities for the oil yield, comes from seed yield differences (Table 5). While the oil yield was $697.6 \mathrm{~kg} \mathrm{ha}^{-1}$ at conventional planting pattern, it increased up to $871.9 \mathrm{~kg} \mathrm{ha}^{-1}$ at twin-row planting pattern.
The highest average oil yield was obtained from $3 \mathrm{~cm}$ intra-row spacing at twin-row planting pattern.

\section{CONCLUSIONS}

Soybean is classified as short day plant. Soybeans flowers very soon after emerge in short day conditions. For this reason, when the planting delayed after June 21, the vegetative growth stage of plants shortened and plants start to flowering due to short day conditions. Other side, in these conditions the plants can not grow tall and the number of the lateral stem was decreased. As a result, pod number per plant and seed number per unit area were decreased. Average seed size and number of seeds per unit area directly effect the yield. In soybean, these parameters can be described in terms of average number of seeds per pod, average number of pods per plant, and number of plants per unit area. It is necessary to increase the plant number per unit area to compensate to reduction of pod number per plant at late planting double crop soybean farming. Increasing the plant number per unit area, it is necessary to reduce the plant space on the rows in singlerow planting pattern. The plants grow thin and weak for competition and the pod number per plant decreases in 
high plant density. It is possible to increase the number of plant per unit area by the twin-row planting pattern. The two years results of this study indicated that increasing plant density per unit area increased the seed yield per hectare. According to a two-year average, the highest seed yield $\left(4906 \mathrm{~kg} \mathrm{ha}^{-1}\right.$ ) was obtained from $80 \times 25 \times 80 \times 3$ $\mathrm{cm}\left(63.2\right.$ plants $\left.\mathrm{m}^{-1}\right)$ twin-row planting pattern while the yield was $3940 \mathrm{~kg} \mathrm{ha}^{-1}$ in conventional single-row planting pattern as $70 \times 4 \mathrm{~cm}\left(35.7\right.$ plants $\left.\mathrm{m}^{-1}\right)$. The yield increase was $24.5 \%$ more than conventional single-row planting pattern (standard). The seed yield per hectare continuously increased as intra row-spacing decreased from $6 \mathrm{~cm}$ to $3 \mathrm{~cm}$ in same twin-row planting pattern. Based on these results; suitable planting pattern could be suggested as twin-row planting and high plant density when the planting delayed after June 21 at double crop soybean planting in Cukurova region of Turkey.

\section{LITERATURE CITED}

Akond, A. G., M. Bobby, R. Bazzelle, W. Clark, S. K. Kantartzi, K. Meksem, and A. Kassem. 2013. Effect of Two Row Spaces on Several Agronomic Traits in Soybean [Glycine $\max ($ L.) Merr.]. Atlas J. of Plant Biology 1(2):18-23

Anonymous. 2014a. The Year Book of Turkish Statistical Institute. Ankara

Anonymous. 2014b. The Meteorological Data for Adana. The Turkish State Meteorological Service Adana Regional Directorship, 2013 and 2014.

Arioglu, H. H. 2014. The Oil Crops Growing and Breeding. The Puplication of University of Cukurova, Faculty of Agriculture, Faculty number: 220, Book Number:A-70, 204 p. Adana-Turkey

Aslam, M., A .K. Naseer, M. Siddique Mirza and Naeemullah. 1993. Effect of Different Row and Plant Spacings on Soybean Yield and Its Components. Pakistan J. Agric. Res. 14(2-3):143- 148

Bell, A. 2005. Higher Yields With Twin-row Soybean. Delta Farm Press, November 14, 2005

Bellaloui, N, H. A.Bruns, H. K. Abbas, A. Mengistu, D. K. Fisher and K. R. Reddy. 2015. Agricultural Practices Altered Soybean Seed Protein, Oil, Fatty Acids, Sugars, and Minerals in the Mid-south USA. Front Plant Science 6:31, Doi: 10.3389/fpls.2015.00031

Bruns, H. A. 2011. Planting Date, Rate, and Twin-Row vs. Single-Row Soybean in the Mid-South. Agronomy J. 103 (5): 1308-1313

Caliskan, S., M. Arslan, I. Uremis and M. E. Caliskan. 2007. The Effect of Row Spacing on Yield and Yield Component of Full Season and Double-Cropped Soybean. Turk J. Agric For. 31: 147-154

Cox, W. J., and J. H. Cherney. 2011. Growth and Yield Responses of Soybean to Row Spacing and Seeding Rate. Agronomy J. 03 (1): 123-128

Dapaah, H. K., S. A. Ennin and J. N. Asafu-Agyei. 2005. Soybean Management for Increased Production: Effects of Plant Population Density and Planting Method. Ghana J. Agric. Sci. NARS Edn No.1: 43-48
Egli, D. B. 1988. Plant Density and Soybean Yield. Crop Sci. 28:977-981

El-Zeadani, H., A. B. Putch, M. M. A. Mondal, A. Selamat, Z. A. Ahmad and M. M. Shalgam. 2014. Seed Growth Rate, Seed Filling Period and Yield Responses of Soybean (Glycine max) to Plant Densities at Specific Reproductive Growth Stages. International J. of Agriculture and Biology $16(5): 923-928$

Hosseini, N. M., R. H. Ellis and B. Yazdi-Samadi. 2001. Effects of Plant Population Density on Yield and Yield Components of Eight Isolines of cv. Clark (Glycine $\max$ L.). J. Agric. Sci.Technol. 3: 131-139

Ikeda, T. 1992. Soybean Planting Patterns in relation to Yield and Yield Component. Agronomy J. 84 (6) 923-926

Koger, C. 2007. Effect of Soybean Row Spacing on Yield: Twin-Row vs. Narrow- and Wide-Rows. 10th Annual National Conservation Systems Cotton and Rice Conference Proceedings Book, p.61

Liu, B., X. Liu, C. Wang, J. Jin, S.J. Herbert and M. Hashemi. 2010. Responsees of Soybean Yield and Yield Components to Light Enrichment and Plant Density. International J. of plant Production 4 (1):1-9

Mascagni, H. J., E. Clawson, D. Lanclos, D. Boquet and R. Ferguson. 2008. Comparing Single-Row, Twin-Row configurations for Louisiana Crop Production. Lousiana Agriculture 51 (3): 16

Ohyama T, R. Minagawa, S. Ishikawa, M. Yamamoto, N. Van Phi Hung, N. Ohtake, K. Sueyoshi, T. Sato, Y. Nagumo and Y. Takahasi. 2013. Soybean Seed Production and Nitrogen Nutrition (Ed:J E Board), Agricultural and Biological Sciences "A Comprehensive Survey of International Soybean Research-Genetics, Physiology, Agronomy and Nitrogen relationships, Intech, Japan, pp. 115-157

Rahman, M. M. and M. M. Hossain. 2011. Plant Density Effects on Growth, Yield and Yield Components of Two Soybean Varieties under Equidistant Planting Arrangement. Asian J. of Plant Sciences Vol.10 (5):278-286

Shamsi, K. and S. Kobraee. 2011. Soybean Agronomic Responses to Plant Density. Annals of Biological Research (4):168-173

Stalcup, L. 2009. Planting Corn and Soybeans in Twin Rows Offers Efficiency. Corn+Soybean Digest, December 1, 2009

Worku, M., and T. Astatkie. 2011. Row and plant Spacing Effects on Yield and Yield Components of Soya Bean Varieties under Hot Humid Tropical Environment of Ethiopia. J. Agronomy and Crop Science 197:67-74

Zaimoglu, B., H. H. Arioglu and M. Aslan. 2004. Effects of Seed Quality on Plant Population and Seed Yield of Double Cropped Soybean in the Mediterranean Region of Turkey. Asian Journal of Plant Science, 3 (5):574-577

Zhou, X. B., Y. H. Chen and Z. Ouyang. 2011. Row Spacing Effect on Leaf Area Development, Light Interception, Crop Growth and Grain Yield of Summer Soybean Crops in Northern China. African Journal of Agricultural Research 6 (6): 1430-1437

Gulluoglu, L., C. Kurt, H. Arioglu, B. Zaimoglu and M. Aslan. 2010. The Researches on Soybean (Glycine max Merr.) Variety Breeding for Resistance to Whitefly in Turkey. Turkish J. of Field Crops 15(2):123-127. 